\title{
Performance of Romanian plum cultivars in the agro-environmental conditions of Plovdiv, Bulgaria
}

\author{
M. Nesheva1*, V. Bozhkova1 and M. Butac ${ }^{2}$ \\ 1Fruit Growing Institute - Plovdiv, Bulgaria. \\ ${ }^{2}$ Research Institute for Fruit Growing Pitesti, Romania. \\ *Corresponding author email: marieta.nesheva@abv.bg
}

\begin{abstract}
Successful plum production requires cultivars well adapted to the specific growing conditions in the area of production. Due to the interaction between environment and genotype, it is very important to evaluate the agronomical and pomological performance of all newly introduced cultivars. The current study aimed to describe the performance of five Romanian cultivars introduced in the agroenvironmental conditions of Plovdiv, Bulgaria. 'Pitestean', 'Roman', 'Romanta', 'Carpatin' and 'Tita' were planted in 2013 in a collection orchard at the Fruit Growing Institute and their phenological stages flow, spring frost resistance, fruit quality and trees productivity were studied for the period 2016-2021. 'Pitestean' was the latest flowering cultivar. In the region, its full flowering phenophase (BBCH 65) occurred 26 days after Stanley. The most severe frost damages in 2019 and 2020 were recorded for 'Roman' $42 \%$ and $96 \%$, respectively. In these two years, 'Tita' showed a very good spring frost resistance and its percentage of damaged flowers was lower than the damages recorded for the standard. 'Romanta' provided very high productivity. 'Tita' and 'Pitestean' cvs. provide qualitative large fruits and an excellent productivity in the environmental conditions of the Plovdiv region. Taking into account the combination of important for the fruit producers characteristics 'Tita', 'Romanta' and 'Pitestean' are suitable for expanding and diversifying the list of cultivars grown. These cultivars could be recommended for introduction in the Bulgarian plum production orchards.
\end{abstract}

Keywords: Prunus domestica L., fruit, productivity, evaluation, cutivar

\section{INTRODUCTION}

Prunus domestica L. is one of the most commonly grown fruit species in Bulgaria due to its high ecological adaptation and multiple ways of fruit marketing possible. The cultivar 'Stanley' is widely grown in the orchards and according to Agrostatistics, in 2019 it occupied $73,4 \%$ of the orchards in the country, followed by 'Cacanska lepotica' with 5,8\% and 'Jojo' $4 \%$. The prevailing single cultivar is a fact that could be changed by improving the plum assortment as a result of new plum genetic resources introduction and establishing new cultivars that comply with the latest issues of producers and consumers (Bozhkova, 2013). Successful plum production requires cultivars well adapted to the specific growing conditions in the area of production. Due to the interaction between environment and genotype, it is very important to evaluate preliminarily the agronomical and pomological 
performance of all newly introduced or released cultivars in the areas in which they will be cultivated (Liverani et al., 2010).

In Romania, the plum is one of the major fruit species grown and it is one of the countries that developed extensive Prunus domestica L. breeding programs. The main breeding objectives were high productivity, good fruit quality and resistance or tolerance to Sharka disease (PPV). The Romanian plum breeding has been started in 1950 and as a result of it, a total number of 40 cultivars were registered (Butac et al., 2013; Butac, 2020). Studies of new plum genetic resources influence directly the breeding process for the selection of donors (Bozhkova and Zhivondov, 2004; Blazek, 2007).

The introduction of new cultivars could improve the plum cultivars structure of the orchards in the country and influence directly fruits production.

In 2013, Romanian cultivars were introduced in Bulgaria and planted in a collection orchard at the Fruit Growing Institute. The aim of this study was to describe this cultivars performance in the agro-environmental conditions of Plovdiv, Bulgaria after 6 years of the cultivars testing.

\section{MATERIALS AND METHODS}

The study was conducted in the period 2016- 2021 in a collection orchard at the Fruit Growing Institute in Plovdiv, Bulgaria. The cultivars 'Pitestean', 'Roman', 'Romanta', 'Carpatin' and 'Tita' were planted in 2013. The orchard was grown on humus carbonate soil, maintained as black fallow, under non-irrigation conditions, at a planting distance of $4 \times 4 \mathrm{~m}$, applying conventional plant protection practices. 'Stanley' cv. was used for comparison.

Phenological data was traced according to the stone fruits BBCH scale (Meier, 2018). In 2019 and 2020 freezing temperatures occurred and the percentage of damaged flowers was calculated. For that purpose, the damage of 100 flowers located in 3 different directions of the crown and up to $2.00 \mathrm{~m}$ high was determined. The harvest date was determined organoleptically.

The fruit quality evaluation included biometrical analyses. Biometric data of an average sample of 25 fruits and their stones were measured with Mitutoyo 500-196-30 Digimatic Absolute Caliper $150 \mathrm{~mm}$.

For evaluation of trees productivity, the yield obtained in 2020 was measured and the canopy volume and productivity index were calculated. Yearly, visual observations for viral symptoms, typical for PPV, on leaves and fruits were performed.

Data were statistically processed by Duncan's multiple range test of the IBM SPSS statistics 26 software.

\section{RESULTS AND DISCUSSIONS}

The phenological stages timing is dependent on a combination of internal (genetic) settings and environmental influences. Studying the cultivars under the different agro-climatic conditions is important for selecting suitable ones for growing in each region of the country and predicting the economic results of them.

In 2019 and 2020 the flowering phenophase for the introduced cultivars started at the end of March and full flowering was recorded in the first decade of April (Table 1). In 2021 the flowering phenophase started at the beginning of April. For the period 2019-2021 the earliest flowering cultivar was 'Roman'. Its full flowering phenophase occurred 0-5 days before the standard cultivar 'Stanley'. 'Pitestean' cv. was the latest flowering cultivar - full flowering phenophase occurred 2-6 days after 'Stanley' cv. 
In Plovdiv region, a considerable number of incidences of spring frosts occurred over the last decade - 2008, 2013, 2016, 2019 and 2020 (Malchev and Savchovska, 2020). Frost injuries of the plum cultivars in Plovdiv region are not a frequent phenomenon and the damages usually are not a very high percentage.

The most severe frost damages in 2019 and 2020 were recorded for 'Roman' cv., 42\% and $96 \%$ respectively. In the two years, 'Tita' cv. showed a very good spring frost resistance and its percentage of damaged flowers was lower than the damages recorded for the standard.

'Stanley' cv. was officially registered as cultivar in 1926, and in the 80's of the 20th century became the main one for our country, gradually occupying about $80 \%$ of the cultivated area (Dzhuvinov et al., 2012). So far, the cultivar is grown widely in the country and in many other countries of Europe. Extending the ripening period is one of the main goals set in many breeding programs and the cultivars which fruits ripen before 'Stanley' cv. are valuable for producers and breeders. In the region of Plovdiv, all of the newly introduced cultivars were ready for harvest before the standard. The earliest ripening cultivar out of the studied group was 'Pitestean' cv.

Table 1. Full flowering date and spring frost damages of the studied cultivars

\begin{tabular}{|c|c|c|c|c|c|c|}
\hline Cultivar & $\begin{array}{c}\text { Full } \\
\text { flowering } \\
\text { date 2019 } \\
\text { (BBCH 65) }\end{array}$ & $\begin{array}{c}\text { Frost } \\
\text { damages } \\
2019(\%)\end{array}$ & $\begin{array}{c}\text { Full } \\
\text { flowering } \\
\text { date 2020 } \\
\text { (BBCH 65) }\end{array}$ & $\begin{array}{c}\text { Frost } \\
\text { damages } \\
2020(\%)\end{array}$ & $\begin{array}{c}\text { Full } \\
\text { flowering } \\
\text { date 2021 } \\
\text { (BBCH 65) }\end{array}$ & $\begin{array}{c}\text { Average } \\
\text { harvest date } \\
\text { 2019- } \\
2020)\end{array}$ \\
\hline 'Pitestean' & April 8 & 24 & April 10 & 0 & April 15 & July 20 \\
\hline 'Roman' & April 1 & 42 & April 3 & 96 & April 9 & July 29 \\
\hline 'Romanta' & April 5 & 22 & April 8 & 32 & April 9 & August 24 \\
\hline 'Tita' & April 5 & 6 & April 8 & 2 & April 13 & July 29 \\
\hline 'Carpatin' & no flowers & - & April 10 & 28 & April 13 & July 27 \\
\hline 'Stanley' & April 3 & 12 & April 8 & 5 & April 9 & August 30 \\
\hline
\end{tabular}

The official fruit quality standard for fruits intended for fresh consumption relies on the fruit size (Polat and Caliskan, 2013). Its main indicator is the fruit weight. The cultivars with larger fruits than the standard 'Stanley'cv., with a statistically non-significant difference, were 'Tita' and 'Roman' cvs. (Table 2).

These cultivars had the largest fruits of the studied group with an average fruit weight of $45.41 \mathrm{~g}$ for 'Tita' and 45.49 $\mathrm{g}$ for 'Roman'. 'Pitestean' had fruits almost the same size as the standard. The other tested cultivars, 'Romanta', and 'Carpatin' had smaller fruit weight than the standard 'Stanley' cv., but with a statistically non-significant difference. All other measured biometric dimension sizes were dependable on the fruit shape and varied slightly in the years.

The size of the stones is highly dependent on the size of the fruit. There is a high correlation between the stone and fruit weight $(r=0.89)$ (Korekar et al., 2013). All of the measured stone sizes were dependable on the fruit dimensions (Table 3).

According to their weight 'Carpatin' cv. had the smallest stones. 'Tita'cv. had the best fruit flesh to stone ratio with the stone relative share of $2.47 \%$ which variation was very low. 


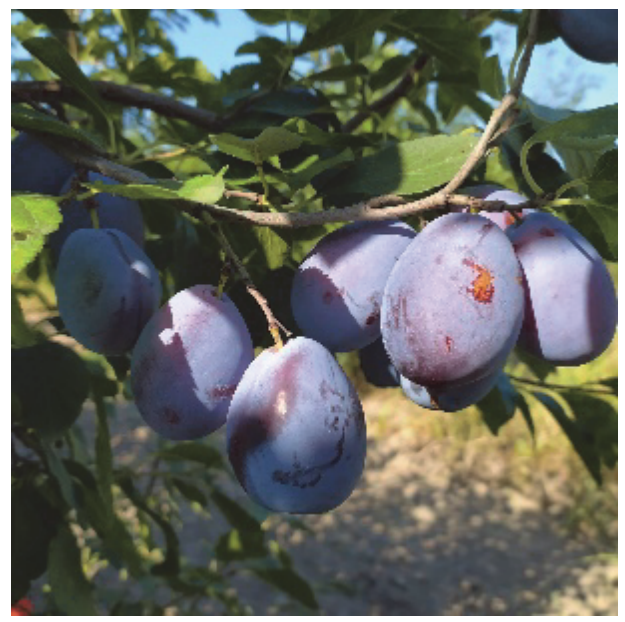

Figure 1. Fruits of 'Tita' cv.

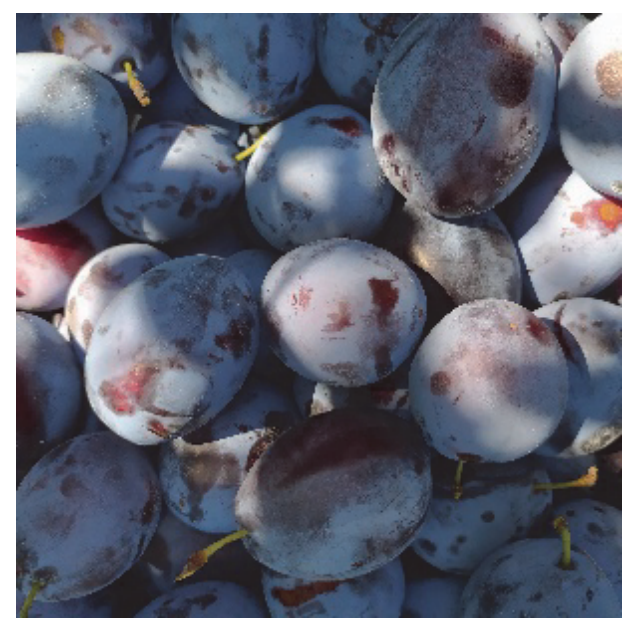

Figure 2. Fruits of 'Pitestean' cv.

Table 2. Average fruit biometric data for the period 2016-2020

\begin{tabular}{|c|c|c|c|c|c|}
\hline Cultivar & $\begin{array}{c}\text { Fruit height } \\
(\mathrm{mm})\end{array}$ & $\begin{array}{c}\text { Fruit width } \\
(\mathrm{mm})\end{array}$ & $\begin{array}{c}\text { Fruit thickness } \\
(\mathrm{mm})\end{array}$ & $\begin{array}{c}\text { Average fruit } \\
\text { weight }(\mathrm{g})\end{array}$ & $\begin{array}{c}\text { Peduncle } \\
\text { length } \\
(\mathrm{mm})\end{array}$ \\
\hline 'Pitestean' & $47.51 \pm 1.90 \mathrm{ab}^{*}$ & $36.89 \pm 2.45 \mathrm{ab}$ & $36.73 \pm 3.07 \mathrm{a}$ & $37.01 \pm 8.86 \mathrm{a}$ & $14.98 \pm 3.07 \mathrm{ab}$ \\
\hline 'Roman' & $47.10 \pm 1.68 \mathrm{bc}$ & $40.74 \pm 3.20 \mathrm{a}$ & $38.51 \pm 1.55 \mathrm{a}$ & $45.59 \pm 6.82 \mathrm{a}$ & $9.95 \pm 1.24 \mathrm{~cd}$ \\
\hline 'Romanta' & $44.32 \pm 4.66 \mathrm{bc}$ & $36.17 \pm 4.42 \mathrm{~b}$ & $35.05 \pm 4.31 \mathrm{a}$ & $34.69 \pm 12.04 \mathrm{a}$ & $13.38 \pm 2.53 \mathrm{abc}$ \\
\hline 'Tita' & $49.17 \pm 2.72 \mathrm{a}$ & $38.83 \pm 1.76 \mathrm{ab}$ & $39.25 \pm 2.54 \mathrm{a}$ & $45.41 \pm 6.84 \mathrm{a}$ & $12.18 \pm 1.49 \mathrm{bcd}$ \\
\hline 'Carpatin' & $43.63 \pm 2.37 \mathrm{c}$ & $36.29 \pm 2.27 \mathrm{~b}$ & $35.55 \pm 2.74 \mathrm{a}$ & $35.14 \pm 6.39 \mathrm{a}$ & $9.53 \pm 1.39 \mathrm{~d}$ \\
\hline 'Stanley' & $48.00 \pm 1.44 \mathrm{ab}$ & $35.89 \pm 2.56 \mathrm{~b}$ & $36.75 \pm 1.46 \mathrm{a}$ & $37 \pm 3.49 \mathrm{a}$ & $16.49 \pm 3.43 \mathrm{a}$ \\
\hline
\end{tabular}

*Mean values followed by a different letter show a statistically significant difference by Duncan's multiple range test $(p<0.05)$.

Table 3. Average stone biometric data for the period 2016-2020

\begin{tabular}{|c|c|c|c|c|c|}
\hline Cultivar & $\begin{array}{c}\text { Stone height } \\
(\mathrm{mm})\end{array}$ & $\begin{array}{c}\text { Stone width } \\
(\mathrm{mm})\end{array}$ & $\begin{array}{c}\text { Stone } \\
\text { thickness } \\
(\mathrm{mm})\end{array}$ & $\begin{array}{c}\text { Average stone } \\
\text { weight } \\
(\mathrm{g})\end{array}$ & $\begin{array}{c}\text { Stone relative } \\
\text { share (\%) }\end{array}$ \\
\hline 'Pitestean' & $26.29 \pm 0.82 \mathrm{a} *$ & $9.29 \pm 3.47 \mathrm{a}$ & $14.30 \pm 3.45 \mathrm{ab}$ & $1.63 \pm 0.28 \mathrm{~b}$ & $4.50 \pm 0.80 \mathrm{a}$ \\
\hline 'Roman' & $27.37 \pm 0.60 \mathrm{a}$ & $9.56 \pm 0.23 \mathrm{a}$ & $16.97 \pm 0.44 \mathrm{a}$ & $2.13 \pm 0.22 \mathrm{a}$ & $4.69 \pm 0.27 \mathrm{a}$ \\
\hline 'Romanta' & $23.75 \pm 2.05 \mathrm{~b}$ & $8.64 \pm 0.89 \mathrm{a}$ & $14.36 \pm 1.44 \mathrm{ab}$ & $1.54 \pm 0.37 \mathrm{~b}$ & $4.54 \pm 0.62 \mathrm{a}$ \\
\hline 'Tita' & $22.19 \pm 1.93 \mathrm{ab}$ & $9.12 \pm 2.42 \mathrm{a}$ & $12.82 \pm 2.79 \mathrm{a}$ & $1.12 \pm 0.18 \mathrm{c}$ & $2.47 \pm 0.22 \mathrm{~b}$ \\
\hline 'Carpatin' & $21.29 \pm 0.85 \mathrm{c}$ & $7.77 \pm 0.43 \mathrm{a}$ & $13.65 \pm 0.63 \mathrm{ab}$ & $1.07 \pm 0.15 \mathrm{c}$ & $3.16 \pm 0.95 \mathrm{~b}$ \\
\hline 'Stanley' & $27.79 \pm 1.42 \mathrm{a}$ & $8.87 \pm 0.29 \mathrm{a}$ & $15.01 \pm 0.68 \mathrm{ab}$ & $1.89 \pm 0.19 \mathrm{ab}$ & $5.17 \pm 0.87 \mathrm{a}$ \\
\hline
\end{tabular}

*Mean values followed by a different letter show a statistically significant difference by Duncan's multiple range test $(p<0.05)$. 
Table 4. Growth and productivity of the trees in 2020

\begin{tabular}{|c|c|c|c|}
\hline Cultivar & $\begin{array}{c}\text { Yield per tree } \\
\text { obtained in 2020 } \\
(\mathrm{kg})\end{array}$ & $\begin{array}{c}\text { Canopy volume } \\
\text { in } 2020\left(\mathrm{~m}^{3}\right)\end{array}$ & $\begin{array}{c}\text { Productivity } \\
\text { index } \\
\text { (yield/canopy } \\
\text { volume) }\end{array}$ \\
\hline 'Pitestean' & $18 \mathrm{a} *$ & $8.19 \mathrm{c}$ & $2.20 \mathrm{c}$ \\
\hline 'Roman' & $2 \mathrm{c}$ & $7.16 \mathrm{~d}$ & $0.28 \mathrm{e}$ \\
\hline 'Romanta' & $20 \mathrm{a}$ & $6.59 \mathrm{e}$ & $3.03 \mathrm{a}$ \\
\hline 'Tita' & $20 \mathrm{a}$ & $8.61 \mathrm{~b}$ & $2.32 \mathrm{~b}$ \\
\hline 'Carpatin' & $11 \mathrm{~b}$ & $6.01 \mathrm{f}$ & $1.83 \mathrm{~d}$ \\
\hline 'Stanley' & $20 \mathrm{a}$ & $9.27 \mathrm{a}$ & $2.16 \mathrm{c}$ \\
\hline
\end{tabular}

*Mean values followed by a different letter show a statistically significant difference by Duncan's multiple range test $(p<0.05)$.

Highly productive cultivars are of greater interest to the fruit growers because they provide a higher profit. The yields obtained in 2020 varied significantly among the cultivars. The lowest yields were obtained from 'Roman' and 'Carpatin' cvs., which was due to the injuries caused by the spring frost that occurred in that year (table 4). The yields obtained by 'Tita', 'Romanta' and 'Pitestean' cvs., were high and had non-significant differences compared to the standard 'Stanley' cv. No matter the high percentage of frost damages the average yield obtained from 'Romanta' cv. was high and it was the most productive cultivar.

'Tita' and 'Pitestean' cvs., had also very good productivity with a significantly higher productivity index compared to the standard. 'Tita', 'Romanta' and 'Pitestean' cvs., were noticed to provide sufficient and regular yields during other years that were not included in the study. Since the trees were planted in the collection orchard, yearly visual observations for symptoms such as light green discoloration, chlorotic spots, streaks or rings, and deformations on fruits were performed. Until 2021 such symptoms were observed on the leaves of all cultivars (Figures 3, 4 and 5). No symptoms were observed on the fruits.

Table 5. Presence (+) or absence (-) of viral symptoms on leaves and fruits

\begin{tabular}{|c|c|c|}
\hline \multirow{2}{*}{ Cultivar } & \multicolumn{2}{|c|}{ Viral symptoms } \\
\cline { 2 - 3 } & Leaves & Fruits \\
\hline 'Pitestean' & + & - \\
\hline 'Roman' & + & - \\
\hline 'Romanta' & + & - \\
\hline 'Tita' & + & - \\
\hline 'Carpatin' & + & - \\
\hline 'Stanley' & + & \\
\hline
\end{tabular}




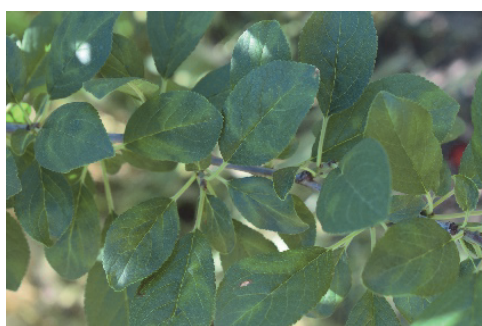

Figure 3. Symptoms observed on the leaves of 'Carpatin' cv.

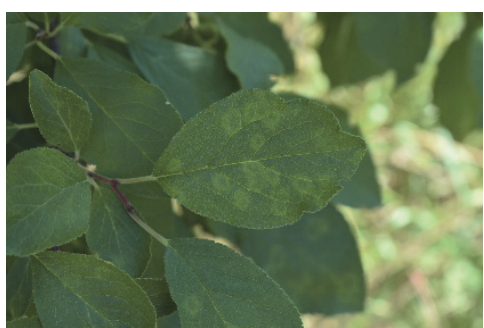

Figure 4. Symptoms observed on the leaves of 'Tita' cv.

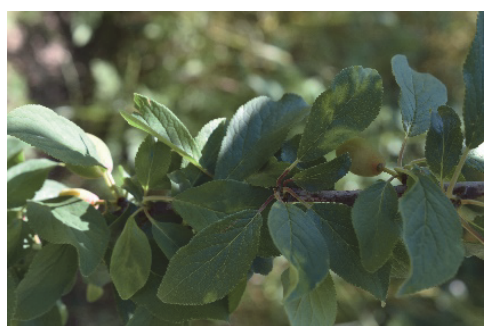

Figure 5. Symptoms observed on the leaves of 'Romanta' cv.

\section{CONCLUSIONS}

In the agro-climatic condition of Plovdiv, Bulgaria the cultivar 'Tita' was considered as resistant to spring frosts and 'Roman' cv. as sensitive and vulnerable to severe frost injuries. 'Romanta'cv. provides very high productivity. The cultivars 'Tita' and 'Pitestean' yield, qualitative large fruits and show excellent productivity in the environmental conditions of the region. Taking into account the combination of important qualities for the fruit producers 'Tita', 'Romanta' and 'Pitestean' cvs. are suitable for expanding and diversifying the list of cultivars grown in the country. These cultivars are recommended for introduction in the Bulgarian plum production orchards.

\section{REFERENCES}

1. Agrostatistics Handbook. (2019). Ministry of Agriculture, Food and Forestry, Sofia,

2. Blazek J. (2007). A survey of the genetic resources used in plum breeding. Acta Hort., 734: 31-45

3. Bozhkova V., Zhivondov A. (2004). Cultivars are commonly used as donors at the breeding for the improvement of plum varietal assortment. Pant sciences, 41: 51-54.

4. Bozhkova V. (2013). Plum genetic resources and breeding. AgroLife Scientific Journal, 2(1): 83-88.

5. Butac, M., Bozhkova, V., Zhivondov, A., Milosevic, N., Bellini, E., Nencetti, V., Blazek, J., Balsemin, E., Lafarque, B., Kaufmane, E., Gravite, I., Vasiljeva, M., Pintea, M., Juraveli, A., Webster, T., Hjalmarsson, I., Trajkovski, V. and Hjeltnes, S.H. (2013). Overview of plum breeding in Europe. Acta Hortic. 981: 91-98

6. Butac M., 2020. Plum breeding. Plum breeding. In: Prunus. Intech Open, London, United Kingdom (Open Access books).

7. Dzhuvinov, V., Dinkova, H., Bozhkova, V. Minev, I., Dragoyski, K., Kutinkova, H., Gercheva, P., Natcheva, L. Stefanova, B. (2012). Plum, Biofrut BG - LTD: 23

8. Korekar, G., Yadav A., Kumar R., Srivastava R. B., Stobdan T. (2013). Multivariate analysis of phenological, pomological, and fruit quality characters in apricot (Prunus armeniaca) grown in trans-Himalayan Ladakh region, India. Indian Journal of Agricultural Sciences, 83(2): 150-8.

9. Liverani, A., Giovannini, D., Versari, N., Sirri, S., Brandi, F. (2010). Japanese and European plum cultivar evaluation in the Po valley of Italy: Yield and climate influence. Acta Hortic. 874: 327-336

10. Malchev, S., Savchovska, S. (2020). Vulnerability of sweet cherry cultivars to continuous periods of spring frosts in Plovdiv, Bulgaria. Agricultural Science and Technology, 12(4): 348-352.

11. Meier, U. (2018). Growth Stages of Mono- and Dicotyledonous Plants. BBCH Monograph (Quedlinburg, Germany: JKI): 204.

12. Polat, A. A., Caliskan O. (2013). Yield and fruit characteristics of various apricot cultivars under subtropical climate conditions of the Mediterranean Region in Turkey.International Journal of Agronomy.

13. Steel, R. G. D., Torrie, J. H. (1960). Principles and procedures of statistics. Principles and procedures of statistics. 